\title{
Political Liberalism, Autonomy, and Education
}

Forthcoming (2020) in: A. Peterson, G. Stahl, H. Soong (eds.), The Palgrave Handbook of Citizenship and Education (Palgrave Macmillan).

Prof. Blain Neufeld

Department of Philosophy

University of Wisconsin - Milwaukee

Milwaukee, WI, 53201

USA

neufeld@uwm.edu

\begin{abstract}
Citizens are politically autonomous insofar as they are subject to laws that are (a) justified by reasons acceptable to them and (b) authorized by them via their political institutions. An obstacle to the equal realization of political autonomy is the plurality of religious, moral, and philosophical views endorsed by citizens. Decisions regarding certain fundamental political issues (e.g., abortion) can involve citizens imposing political positions justified in terms of their respective worldviews upon others. Despite citizens' disagreements over which worldview is correct, 'political liberalism' claims that there is a form of political autonomy that is realizable within pluralist societies. (Political liberalism differs from 'comprehensive liberalism' by, inter alia, being 'freestanding' vis-à-vis citizens' different worldviews.) Citizens can be politically autonomous if they enjoy equal political power and justify its exercise with 'public reasons.' A political liberal education would aim at ensuring that all students can become politically autonomous citizens by teaching them how to exercise their democratic rights effectively and how to engage in public reasoning. Some political and educational theorists, however, argue that teaching students how to be politically autonomous amounts to teaching them how to be 'comprehensively' autonomous. If this is so, then the distinction between political liberalism and comprehensive liberalism collapses, at least with respect to education. This chapter outlines the main elements of political liberalism, summarizes the main requirements of a political liberal citizenship education, and surveys three arguments in support of and against the thesis that a political liberal education amounts to an education for comprehensive autonomy.
\end{abstract}

\section{Key words}

Autonomy, citizenship, civic education, democratic citizenship, liberalism, political autonomy, political liberalism, public reason, Rawls, reasonable pluralism 


\section{Introduction}

Within a legitimate political society, Jean-Jacques Rousseau contends, "the words 'subject' and 'sovereign' are identical correlatives, the meaning of which is brought together in the single word 'citizen"' (Rousseau 1968: 138). Rousseauian citizens possess what later philosophers refer to as 'political autonomy' (e.g., Rawls 2005). Leaving aside the idiosyncrasies of Rousseau's account, the general idea of political autonomy is that citizens are politically autonomous insofar as they are subject to laws that are justified by reasons that are acceptable to them and are authorized by them via their political institutions.

An obstacle to the realization of political autonomy within contemporary liberal democratic societies is the plurality of religious, moral, and philosophical views endorsed by citizens (e.g., Buddhism and utilitarianism). This pluralism cannot be eliminated without the exercise of politically oppressive power, something that liberalism's commitment to toleration rules out. Yet accommodating this pluralism seems to prevent the realization of all citizens' political autonomy. This is because decisions regarding certain fundamental political issues-for instance, what the laws should be concerning abortion or physician-assisted suicide-can involve citizens imposing political positions justified in terms of their respective worldviews upon others. If this is so, then not all citizens can be politically autonomous: many will be subject to laws that are justified by reasons that they cannot accept.

Despite citizens' disagreements over which worldview is correct, 'political liberalism'- the account of legitimacy and justice developed most famously by John Rawls (2001, 2005) — claims that there is a form of political autonomy that is realizable within pluralist societies. Citizens can be politically autonomous if they enjoy (roughly) equal political power and justify the exercise of that power vis-à-vis fundamental political matters with 'public reasons.' A political liberal educational system would aim at ensuring that all students become politically autonomous citizens. Educationally, this would involve teaching students how to exercise their democratic rights effectively and how to engage in public reasoning.

Can students be taught to be politically autonomous without teachers and schools also cultivating within them a 'comprehensive' form of autonomy, that is, a form of autonomy that encompasses not simply political matters but all or most dimensions of persons' lives? If not, then political autonomy may not be achievable for many citizens after all. This is because comprehensive autonomy is an ideal that many citizens reject (for instance, those who endorse certain kinds of religious views). Such citizens will find it difficult if not impossible to support an educational system that inculcates or promotes that ideal in their children. If teaching political autonomy necessarily involves teaching comprehensive autonomy, then political liberalism's accommodation of pluralism may be quite limited.

This chapter surveys the debate concerning political liberalism, autonomy, and education. The focus will be on Rawlsian political liberalism. (Similar versions of political liberalism are presented in: Cohen 1999, 2008; Larmore 1987, 2008; Nussbaum 2011; Quong 2011; and Watson and Hartley 2018.) The core elements of political liberalism are outlined in \$I. The main requirements of a political liberal citizenship education are summarized in $\$ I I$. Three arguments that such an education amounts to an education for comprehensive autonomy are considered in \$III, along with replies to those arguments. Concluding remarks are in $§ I V$. 


\section{Political liberalism}

\section{I.a. Reasonable pluralism}

A central claim of political liberalism is that citizens living in societies that respect basic liberal rights, including liberty of conscience, invariably will subscribe to a range of incompatible philosophical, moral, and religious "comprehensive doctrines" (e.g., Islam, secular humanism, etc.). Such doctrines apply to most or all aspects of persons' lives. Rawls calls this the "fact of reasonable pluralism" (Rawls 2005: 36f, 441). This pluralism can be eliminated only through the exercise of political oppression (Rawls 2005: 37 ).

\section{I.b. A political conception of justice}

In order to accommodate the fact of reasonable pluralism while respecting citizens' equal standing, Rawls holds that society should be organized by a 'political conception of justice.' Such a conception satisfies what may be called the 'basic structure restriction' and the 'freestanding condition.' According to the basic structure restriction, a political conception of justice applies directly only to society's 'basic structure': its main political and economic institutions, understood as an overall system of cooperation encompassing all citizens. 'Voluntary associations' like religious institutions may organize themselves internally in other ways - their governance, for instance, need not be democratic-but they cannot violate the rights of citizens that are secured by the basic structure, including those of their members. A political conception of justice satisfies the freestanding condition by being formulated in terms of distinctly 'political' ideas (concepts, principles, ideals, and values). Such political ideas do not presuppose the truth of any particular comprehensive doctrine. Instead, they are construed as implicit within the public political culture of democratic society, namely, the conceptions of citizens as free and equal, and society as a fair system of cooperation. Hence a political conception of justice is compatible with (and ideally integrated into) the different comprehensive doctrines endorsed by citizens (Rawls 2005: 11-16, 374-76). A 'comprehensive' conception of justice, in contrast, is based upon a particular comprehensive doctrine (say, utilitarianism) and/or applies directly to areas of life beyond the basic structure.

Consider the conception of justice that Rawls defends as the most reasonable one: 'justice as fairness.' This conception consists of two principles, the first of which enjoys 'lexical priority' over the second (Rawls, 1999: 132, 266-267, 2001: 46-47). The first principle secures a set of 'basic liberties' - freedom of association, the political liberties, and so forth-equally for all citizens. The second principle consists of two sub-principles: (a) the 'fair equality of opportunity' principle, which regulates the distribution of unequal positions of authority, wealth, and income, and (b) the 'difference principle', which concerns (inter alia) society's overall distribution of income and wealth. (See Rawls 2001: 42-43.) An account of the stability of a society that complies with these principles is advanced in Part III of $A$ Theory of Justice (Rawls 1999/1971). This account, however, violates the freestanding condition: it presupposes elements of a comprehensive doctrine. Hence it is a (partially) comprehensive conception of justice (Rawls 2001: 186-87; see also Weithman 2010). In contrast, the revised version of justice as fairness is a political conception, as its account of stability satisfies the freestanding condition (see Rawls 2001: Part V; 2005: Lecture IV). 


\section{I.c. Citizens as reasonable persons}

A core idea of political liberalism is that of citizens as capable of being reasonable persons. Reasonable persons acknowledge the fact of reasonable pluralism and share a commitment to satisfying what Rawls calls the "criterion of reciprocity" when justifying fundamental political decisions to one another (Rawls 2005: xliv, 16, 49-50, 54). The criterion of reciprocity is the "intrinsic (moral) political ideal" of political liberalism (Rawls 2005, xlv). In order to satisfy this criterion, citizens must justify their proposals concerning "constitutional essentials" and "matters of basic justice" (Rawls 2005: 214-15, 227-30, 235) in terms that other citizens — or at least those similarly committed to the criterion of reciprocity (see Lister 2018) — find acceptable. The reasonableness of persons expresses itself in what Rawls calls the first "moral power" of citizens: their capacity to form and act upon a "sense of justice" (Rawls 2001: 18-19, 196).

\section{I.d. Civic respect and public reason}

One way to understand how citizens can be reasonable persons is to see reasonableness as involving a form of mutual respect (see Edenberg 2016). Given its political context, this conception of mutual respect can be termed 'civic respect' (Neufeld 2005, 2019). Civic respect has four features:

1. Civic respect requires that citizens acknowledge the fact of reasonable pluralism.

2. Civic respect is a form of 'recognition respect' (Darwall 1995, 2006). Recognition respect, roughly, is that respect which is owed to persons in virtue of some characteristic that they possess. This characteristic grants such persons a certain standing in their relations with others. Civic respect is the form of recognition respect that is owed to persons in virtue of their standing as free and equal citizens. One expresses such respect by taking this standing into account when deciding fundamental political questions in concert with one's fellow citizens.

3. Because civic respect is owed to persons qua citizens, it is limited in its scope to relations among citizens within the basic structure of society.

4. Civic respect requires that citizens decide questions regarding constitutional essentials and matters of basic justice in a way that satisfies the criterion of reciprocity — that is, given the first three features of civic respect, in accordance with the idea of 'public reason.'

'Public reasoning' is the form of reasoning that Rawls maintains citizens should use when deciding fundamental political questions. The idea of public reason should be understood as "part of the idea of democracy itself" (Rawls 2005: 441). The terms of public reasonparticular 'public reasons'-are provided by the family of 'reasonable' political conceptions of justice endorsed by citizens. A 'reasonable' political conception of justice is one that, in addition to satisfying the freestanding condition and the basic structure restriction, also satisfies the criterion of reciprocity. In order to satisfy this criterion, that conception must give priority to securing the basic rights and liberties of democratic citizenship equally for all, and, moreover, ensure that all citizens have adequate resources to exercise effectively those rights and liberties over the course of their lives (Rawls 2005: 450). Rawls holds that justice 
as fairness is "the most reasonable conception because it best satisfies these conditions" (Rawls 2005: xlvi). Public reasons also may include the methods and conclusions of transparent forms of inquiry (such as those of logic and the sciences).

Decisions concerning constitutional essentials and matters of basic justice made via public reasoning satisfy the "liberal principle of legitimacy" (Rawls 2005: xliv, 137). Such decisions have normative authority for citizens (Rawls 2005: 19). This is because the public reasons that are used to justify those decisions are acceptable to all reasonable citizens.

\section{I.e. The duty of civility and the public political forum}

When citizens use public reasons to decide fundamental political questions, they realize what Rawls calls their "duty of civility" (Rawls 2005: 444). This duty applies primarily to public officials within the 'public political forum.' This forum is where national political issues are debated and authoritative decisions regarding them are made. It consists of three parts: "the discourse of judges in their decisions, especially of the judges of a supreme court; the discourse of government officials, especially chief executives and legislators; and [...] the discourse of candidates for public office" (Rawls 2005: 443). Other citizens, however, are not exempt from the duty of civility: they fulfill it by holding public officials to the idea of public reason when evaluating their performance within the public political forum, especially (though not exclusively) when voting (Rawls 2005: 444-445).

Political debates need not employ public reasons alone. Reasons drawn from particular comprehensive doctrines can be introduced in the public political forum, so long as what Rawls calls 'the proviso' is satisfied. The proviso is satisfied if "proper political reasons-and not reasons given solely by comprehensive doctrines_-are presented that are sufficient to support whatever the comprehensive doctrines introduced are said to support" (Rawls 2005, 462). For instance, a utilitarian legislator could explain her support for a law permitting physician-assisted suicide on utilitarian grounds (arguing, roughly, that such a law would maximize overall utility), so long as she also provided a justification in terms of public reasons (say, that the law in question best respects citizens' equal freedom to control their own lives). Moreover, political debates outside of the public political forum-discussions within civil society, what Rawls calls the 'background culture'-need not use public reasons (Rawls 2005: 442-443). Nonetheless, the duty of civility requires sufficient public reason justifications for all decisions concerning constitutional essentials and matters of basic justice.

\section{I.f. Citizens as rational persons}

Citizens also are characterized in political liberalism as capable of being rational persons. Citizens' rational nature includes what Rawls refers to as their second moral power: the capacity to form, revise, and pursue conceptions of the good. A conception of the good "is an ordered family of final ends and aims which specifies a person's conception of what is of value in human life or, alternatively, of what is regarded as a fully worthwhile life" (Rawls 2001: 19). Rational persons determine for themselves what kinds of lives have value, and they pursue or revise their life-plans in accordance with those determinations over time. 


\section{I.g. Citizens' higher-order interests}

Citizens' opportunities to exercise effectively their two moral powers-their capacities to form and act upon conceptions of justice and the good-over the course of their lives constitute their "higher-order interests" (Rawls 2005: 74-75, 106). Moreover, citizens' reasonable nature, their sense of justice, constrains their rational pursuit of their conceptions of the good. (For more on the reasonable and the rational, see Rawls 2001: 6-7, 81-82, 191.)

This conception of citizens, Rawls stresses, "is meant as both normative and political, not metaphysical or psychological" (Rawls 2001: 19). It is an ideal that most persons with adequate education and resources are capable of realizing in their lives (at least well enough to be considered equal citizens). Reasonable political conceptions of justice are formulated with reference to this conception of citizens: principles of justice are those that citizens can support freely given their higher-order interests (their interests in being able to exercise the moral powers). This normative political conception of citizens, moreover, is freestanding in nature, and hence compatible with different comprehensive doctrines.

\section{I.h. Full political autonomy}

When citizens are committed to interacting with one another on the basis of civic respect it is possible for them all to enjoy and exercise 'full political autonomy.' There are two elements to citizens' full political autonomy, what can be termed 'institutional autonomy' and 'justificatory autonomy.’

Institutionally autonomous citizens possess the rights and resources that enable them to take part as (roughly) equal contributors to their society's main decision-making processes. Citizens exercise institutional autonomy "by participating in society's public affairs and sharing in its collective self-determination over time" (Rawls 2005: 78). Hence the equal political liberties - including the rights to vote and run for public office-must be part of any reasonable political conception of justice.

Citizens enjoy justificatory autonomy when fundamental political decisions are made using reasons that they find acceptable (Rawls 2005: 77). Public reasoning makes possible citizens' justificatory autonomy despite the fact of reasonable pluralism. But although public reasons are acceptable to all, citizens may reach different conclusions concerning particular political questions. It is to be expected that individuals will give different weights to different public reasons and, moreover, interpret them in somewhat different ways. As Rawls says, "this is the normal case: unanimity of views is not to be expected" (Rawls 2005: 479). Even when they disagree over which political positions are the most reasonable, though, citizens possess justificatory autonomy insofar as the positions selected are supported by public reasons.

Public reasoning, then, "is the form of reasoning appropriate to equal citizens who as a corporate body impose rules on one another backed by sanctions of state power" (Rawls 2001: 92). Such citizens are simultaneously 'subjects' and 'sovereigns.' They are politically autonomous by exercising their political liberties to help decide fundamental political decisions via public reasons (see Rawls 2005: xliv; for discussion see: Neufeld 2019; Watson and Hartley 2018; and Weithman 2011, 2017, 2018). 


\section{Political liberal citizenship education}

II.a. Educating students to become reasonable and rational persons

A political liberal education for citizenship would teach students the skills, concepts, and virtues necessary for them to become capable of being reasonable and rational persons as adults. Teaching students how to be rational persons would involve ensuring that they know how to use their rights and resources to form, revise, and pursue conceptions of the good. Cultivating reasonableness in students would involve teaching them how to interact with others on the basis of civic respect. Students consequently would learn how to be fully politically autonomous and respect the political autonomy of others. This is because they would learn how to exercise their democratic rights effectively (institutional autonomy) and how to justify to others their positions regarding fundamental political matters with public reasons (justificatory autonomy).

\section{II.b. Political versus comprehensive autonomy}

Rawls distinguishes between political autonomy and comprehensive autonomy-the latter often also is referred to as 'ethical' autonomy (the terms 'ethical autonomy' and 'comprehensive autonomy' will be used interchangeably hereinafter). Comprehensive autonomy (inter alia) applies to the whole (or most aspects) of persons' lives. While political liberalism "affirms political autonomy for all," Rawls claims that it "leaves the weight of ethical autonomy to be decided by citizens severally in light of their comprehensive doctrines" (Rawls 2005, 78). Democratic citizens are to help to determine the laws to which they all are subject; whether to value and exercise autonomy in the other dimensions of their lives is to be left to them.

Does this distinction between political and comprehensive autonomy have educational implications? Rawls thinks that it does. In Political Liberalism he briefly considers the scope of the "requirements the state can impose" on the education of children belonging to "religious sects [that] oppose the culture of the modern world and wish to lead their common life apart from its unwanted influences." Comprehensive liberal approaches to education, Rawls explains, "may lead to requirements designed to foster the values of autonomy and individuality as ideals to govern much if not all of life." By contrast, "political liberalism has a different aim and requires far less" (Rawls, 2005, 199). Because it aims only at political autonomy, which is limited in its scope to society's political decision-making processes (see \I.h), Rawls holds that a political liberal educational system can accommodate the beliefs and practices of the members of the religious sects in question.

\section{II.c. Comprehensive autonomy: substantive autonomy}

Before considering the relation between political and comprehensive autonomy, a clearer understanding of what the latter involves is needed. There are many 'conceptions' of the 'concept' of autonomy-Rawlsian political autonomy is an example of a particular conception. (On the distinction between 'concepts' and 'conceptions,' see Rawls 1999: 5; for discussion of this distinction with respect to autonomy, see Dworkin 1988: 9-10.) Which 
conception (or family of conceptions) does Rawls have in mind when he distinguishes ethical autonomy from his conception of political autonomy?

When he refers to ethical autonomy, Rawls seems to have in mind something like what Gerald Dworkin calls 'substantive' autonomy (Dworkin 1988; see also the discussion of 'autonomy' in Benn 1988). A life lived autonomously, in this sense, requires that persons critically reflect on their deepest ends and beliefs, and display a kind of 'independence' by not deferring (at least not usually) to others, including authorities (e.g., religious or community leaders), on such questions. Substantive ethical autonomy also may involve a willingness to explore, or at least seriously consider, alternative ways of life (projects, lifeplans, and the like). According to Rawls, citizens can be politically autonomous even if they are not substantively (ethically) autonomous (say, by accepting their religious views on the basis of faith and community, and not through independent rational reflection).

\section{Political and comprehensive autonomy: for and against the convergence thesis}

Some political liberals defend Rawls's claim that an education for political autonomy differs from, and is generally less demanding than, one for comprehensive autonomy (Davis and Neufeld 2007; De Wijze 1999; Ebels-Duggan 2013; Neufeld 2013). This position, though, has been challenged by a number of theorists who have written on this topic. Some political liberals maintain that political liberalism requires a form of education for citizenship that is much more demanding than that suggested by Rawls (Costa 2011; Macedo 2000; Schouten 2018). And some comprehensive liberals contend that teaching Rawlsian political autonomy amounts to teaching comprehensive autonomy (Callan 1996, 1997; Gutmann 1995;

Kymlicka 2001: Chap.17). This section presents three arguments in support of the claim that an education for political autonomy 'converges' with an education for comprehensive autonomy-hereinafter referred to as the 'convergence thesis' - as well as some replies to those arguments.

III.a. The first moral power argument for the convergence thesis

The first kind of argument in support of the convergence thesis focuses on the educational goal of creating reasonable citizens, specifically, the goal of ensuring that students acquire, and learn how to exercise effectively, a sense of justice (the first moral power). This requirement involves ensuring that students know how to engage in the public life of their society in order to promote the political values and principles of justice that they judge to be the most reasonable. According to some defenders of the convergence thesis, the goal of teaching students how to be effective democratic citizens amounts to teaching them how to be comprehensively autonomous, even if this is not the explicit goal of such an education.

Amy Gutmann, writing from a comprehensive liberal perspective, maintains that despite the theoretical soundness of Rawls's distinction between political and comprehensive autonomy, there is no practical difference between them, at least when it comes to educating future citizens. This is because, according to Gutmann, "most (if not all) of the same skills and virtues that are necessary and sufficient for educating children for citizenship in a liberal democracy are those that are also necessary and sufficient for educating children to deliberate about their way of life, more generally (and less politically) speaking" (Gutmann 1995: 573). In practice at least, teaching citizens to become politically autonomous amounts 
to teaching them to be comprehensively autonomous. (See also Kymlicka 2001 and Reich 2002: ch.2.) (Gutmann (1995) also advances an argument in support of the convergence thesis based on a shared commitment among political and comprehensive liberals to teaching mutual respect to students. Davis and Neufeld (2007: 53-60) contend that Gutmann's argument fails because the conception of civic respect (see $\$$ I.d) differs from-and has less demanding educational requirements than-the comprehensive liberal conception of mutual respect endorsed by Gutmann.)

Gutmann's argument for the convergence thesis finds indirect support in the account of citizenship education advanced by the political liberal Stephen Macedo. Macedo calls his version of political liberalism 'civic liberalism' and holds that it is committed to a 'transformative project': liberal institutions must "mold people in a manner that ensures that liberal freedom is what they want" (Macedo 2000: 15, Macedo's italics). Furthermore, Macedo defends what he calls 'civic autonomy,' according to which students are "provided with the intellectual tools necessary to [...] formulate their own convictions, and make their own way in life" (238). "[P] romoting [...] core liberal values," Macedo writes, "will probably have the effect of encouraging critical thinking in general." Consequently, "Liberal civic virtues and attitudes will spill over into other spheres of life"; indeed, a liberal society's institutions and practices must "work to transform the whole of the moral world in the image our most basic political values" (Macedo 2000: 179, 151).

Macedo characterizes civic liberalism as a form of political liberalism by appealing primarily to the freestanding condition (Macedo 2000: 166-174). The basic structure restriction, in contrast, does not seem to be part of civic liberalism. Macedo claims that the liberal distinction between public and private life is only "superficial" in nature: "In a deeper sense," he maintains, "liberal institutions and practices shape all of our deepest moral commitments" (164). Hence while "[p]ublic educational institutions should not promote comprehensive ideals of life as a whole [...] that does not mean that public schools are limited to a narrowly political agenda." This is because, according to civic liberalism, "Our civic ideals are not narrowly political" (239). Consequently, the requirements of a civic liberal citizenship education include promoting in students a capacity for civic autonomy and a willingness to exercise that capacity in most if not all domains of social life. Macedo, then, ultimately seems to concur with Gutmann that political and comprehensive liberals converge (for the most part) on the same demanding account of citizenship education, differing only in their distinct rationales for that account.

Both Macedo and Gutmann, in short, hold that teaching students how to be effective democratic citizens - how to exercise their first moral power-involve teaching skills and concepts that invariably spill over into other areas of students' lives, thereby teaching them a comprehensive form of autonomy.

\section{III.b. Against the first moral power argument}

Those who defend the distinction between political and comprehensive autonomy do not deny that teaching students to become politically autonomous might lead some (perhaps many) to come to value and exercise a more comprehensive form of autonomy (Rawls 2005, 199-200). Nonetheless, they maintain that the kinds of spill-over effects described by Gutmann and Macedo do not demonstrate that teaching political autonomy and teaching 
ethical autonomy are indistinguishable in practice. Davis and Neufeld hold that convergence in educational practice is nether conceptually nor practically inevitable - there exists a 'gap,' in both theory and practice, between teaching students the political ideas necessary for free and equal citizenship, and teaching students a form of comprehensive autonomy (Davis and Neufeld 2007: 60, n.41; Neufeld 2013). Classes that aim to teach students how to be politically autonomous, roughly, teach them about their rights and liberties as citizens, the political virtues, and how to participate in the political decision-making processes of their society. Such classes differ from those that aim to teach students to be ethically autonomous. The latter kind of classes would encourage students to reflect critically on their comprehensive beliefs and values, including their religious ones, as well as those of other students.

A pedagogic strategy for teaching students how to be politically autonomous-in particular, how to interact with others on the basis of civic respect—is described by Davis and Neufeld (2007). Students would participate in formal debates concerning a range of fundamental political issues. Such issues could be both historical (concerning, say, pivotal constitutional issues in the history of their county) and contemporary in nature (regarding distributive justice, marriage, physician-assisted suicide, abortion, alternative electoral systems, and the like). After explaining to students that they live in a society characterized by persistent disagreement over a wide range of religious and moral questions, the rules of the debate would be introduced. The key rule would be that students defend their positions concerning fundamental political issues with public reasons. Positions defended without sufficient public reasons would be ruled inadmissible. Students would be encouraged to rise on 'points of order' in order to help them identify arguments that violate the duty of civility. (For instance, an argument offered in support of same-sex marriage based exclusively on utilitarian considerations would be ruled inadmissible; an argument that appealed to the free and equal status of citizens, in contrast, would be admissible.) Through their participation in such debates, students would learn how to employ public reasons when deciding fundamental political questions. (But these debates need not exclude comprehensive doctrines altogether-recall Rawls's proviso (see $§ I . e$.$) . Hence students could provide non-public$ reasons for their positions so long as they also provide sufficient public reasons.)

Such exercises would teach students how to exercise political autonomy without necessarily exposing their comprehensive beliefs and values to rational scrutiny. Davis and Neufeld (2007) concede that some students may choose to scrutinize their comprehensive doctrines as a result of their participation in such debates (and similar educational exercises), and thereby come to value and exercise comprehensive autonomy. Such broader critical scrutiny, though, is not necessary or unavoidable.

\section{III.c. The burdens of judgement argument for the convergence thesis}

Eamonn Callan advances another argument for the convergence thesis (1996, 1997). Callan's argument focuses on reasonable persons' acceptance of the fact of reasonable pluralism, specifically, on Rawls's idea of the "burdens of judgement" (Rawls 2005: 54-58). Rawls sketches six factors - such as the indeterminacy of many of our moral concepts and citizens' diverse life-experiences - that make up these burdens. The idea of the burdens of judgement is advanced by Rawls to help explain the fact of reasonable pluralism, that is, why people reasoning well nonetheless may come to endorse different comprehensive doctrines. 
Rawls's distinction between political and comprehensive autonomy can be seen to be "bogus," according to Callan, "once we reflect on the educational task of securing active acceptance of the burdens of judgement" (Callan 1996: 21). An education designed to secure such 'active' acceptance is indistinguishable from an education designed to foster ethical autonomy. This is because, Callan contends, "nominal assent to a list of abstractions is not enough; the relevant acceptance must rather be an active and onerous psychological disposition, pervasively shaping the beliefs we form and the choices we make" (Callan 1996: 15; see also 1997: 34, 180f, 217f). Callan concludes: "the psychological attributes that constitute an active acceptance of the burdens [...], such as the capacity and inclination to subject received ethical ideas to critical scrutiny, also constitute a recognizable ideal of ethical autonomy" (Callan 1996: 21). Hence educating students to actively accept the burdens of judgement — as part of educating them to be reasonable persons - amounts to educating them to be ethically autonomous.

\section{III.d. Against the burdens of judgement argument}

In presenting the idea of the burdens of judgement, Rawls denies that it requires that citizens become "hesitant and uncertain, much less sceptical, about [...] [their] own beliefs" (Rawls 2005: 63). Drawing on recent work in epistemology on peer disagreement, Fabienne Peter (2013) defends a view similar to Rawls's concerning the relation between acceptance of the fact of reasonable pluralism and citizens' confidence in the truth of their comprehensive doctrines. On the question of how to teach students to become reasonable persons, Kyla Ebels-Duggan (2013) proposes that students can be taught to accept the fact of reasonable pluralism, and acknowledge that other comprehensive doctrines can be endorsed by reasonable persons, without also teaching them to question or doubt the truth of their own comprehensive doctrines. Davis and Neufeld (2007: 60-67) explicitly defend Rawls's modest interpretation of what acceptance of the burdens requires of citizens; they use possible lessons on the history of religious conflicts to defend their view with respect to educating students about the fact of reasonable pluralism. (See also Edenberg 2016.)

Even if Callan's interpretation of the burdens of judgement is correct, though, political liberals could respond by claiming that students do not need to be taught to accept the burdens in order to become reasonable persons (see Strike 1996 and Wenar 1995). The burdens of judgement may not be the only way to explain the fact of reasonable pluralism. So long as students learn how to interact with others on the basis of the principle of civic respect, including how to use public reasons to decide fundamental political questions, they can learn to be reasonable persons. Such a response still requires that students learn how to be politically autonomous, but because it does not require the acceptance of the burdens of judgement in the way presupposed by Callan, it does not seem to involve the necessary cultivation of ethical autonomy.

\section{III.e. The second moral power argument for the convergence thesis}

The two arguments for the convergence thesis discussed above focus on teaching students how to be reasonable persons. But what about the goal of teaching students to be rational persons, specifically, persons with the capacity to form, revise, and pursue conceptions of the good? The argument for the convergence thesis advanced by Gina Schouten (2018) rests 
on the purported instrumental value of autonomy for securing students' future interests with respect to the second moral power. Schouten calls this a 'student-centered' argument for the convergence thesis, as it has to do with the future ability of all students to live good lives, rather than their future roles in promoting and maintaining the justice of their society's basic structure.

Schouten's argument focuses on what is needed for citizens to exercise effectively their rights and resources vis-à-vis their second moral power. Rawls calls the rights and resources necessary for citizens to exercise their two moral powers - things such as the basic liberties, income and wealth, and so forth-'primary goods' (Rawls 2001: 57-61). All reasonable political conceptions of the justice secure for all citizens (at least) sufficient primary goods for them to exercise effectively their two moral powers over the course of their lives. With respect to citizens' second moral power, the primary goods are used to form, revise, and pursue conceptions of the good. Basic liberties like liberty of conscience and freedom of association, along with resources like education, income, and wealth, enable citizens to determine and act upon their plans, commitments, relationships, and the like.

Schouten points out that different conceptions of the good are suitable for the flourishing of different people: "There are perfectly good lives that some can live well while others cannot" (Schouten 2018: 1090). If this is so, then persons must be able to use the primary goods that they have available to them as citizens in order to figure out which conceptions of the good have value_-are a 'good fit'-for them. But this capacity, she contends, just is a 'basic capacity for robust autonomy" (Schouten 2018: 1090). An education for robust (comprehensive) autonomy, then, is justified on political grounds as a kind of 'safeguard' to ensure that all citizens - if necessary - will be able to identify and pursue conceptions of the good that are appropriate for them (even if not all citizens will need to do this). The capacity for robust autonomy, then, helps ensure that students will not end up living lives that are not good fits for them because of factors outside of their control, such as the communities and families within which they were raised. (A similar claim is sketched in Brighouse 1994.)

\section{III.f. Against the second moral power argument}

Political liberals sympathetic to the Rawlsian position can point out that Schouten's argument fails to distinguish adequately between 'conceptions of the good'-the concern of citizens' second moral power-and 'comprehensive doctrines.' Some political liberals do not distinguish clearly between these ideas (e.g., Nussbaum 2011). In Rawls's later writings on political liberalism, though, these ideas play distinct roles. A conception of the good is not itself a comprehensive doctrine. Rather, "[t]he elements of such a conception are normally set within, and interpreted by, certain comprehensive religious, philosophical, or moral doctrines in the light of which the various ends and aims are ordered and understood" (Rawls 2001: 19). So, for instance, two people might endorse conceptions of the good that include artistic excellence and rich family relationships. Yet one person might interpret this conception from within a Jewish perspective while the other does so from within a utilitarian perspective. Consequently, their understandings of these elements will be quite different.

This distinction threatens Schouten's argument. Citizens who adhere to different comprehensive doctrines often will exercise their second moral power in quite different ways, according to different evaluative criteria and drawing on different resources. For instance, 
the evaluative criteria and resources that a devout Catholic will employ when deliberating about which life-plan to pursue will be quite different from those employed by a secular humanist_ - among other things, faith and the pronouncements of relevant religious authorities will play a role in the former's deliberations that they do not in those of the latter. The exercise of the second moral power, then, does not seem to require the exercise of robust autonomy any more than it seems to require the use of faith - the appropriate roles of robust autonomy and faith in citizens' exercises of their second moral power are shaped by their respective comprehensive doctrines. Of course, citizens are free to change their comprehensive doctrines and students must be taught "that liberty of conscience exists in their society and that apostasy is not a legal crime" (Rawls 2005: 199). But learning these things does not require more than learning to understand and exercise political autonomy. Schouten's argument, then, arguably presupposes a comprehensive liberal interpretation of what exercising the second moral power necessarily involves.

\section{Conclusion}

This chapter outlined some of the main arguments in support of and against the convergence thesis. Opponents of the convergence thesis hold that Rawls is correct in claiming that teaching political autonomy requires 'less' than teaching ethical autonomy. Consequently, opponents of the convergence thesis conclude that, ceteris paribus, the kind of citizenship education required by political liberalism is compatible with a range of educational options for students and families that reflect the reasonable pluralism of their societies. In other words, opponents of the convergence thesis generally are sympathetic to forms of educational choice for families that accommodate citizens' diverse comprehensive doctrines while at the same time ensuring that all students learn how to become rational and reasonable persons (see Davis and Neufeld 2007, Ebels-Duggan 2013, and Edenberg 2016). In contrast, defenders of the convergence thesis, because they contend that all students need to learn to become ethically autonomous, generally are less sympathetic to any decentralization of citizenship educational requirements, at least with respect to curriculum content and pedagogy. These are general tendencies, however, as political liberals who agree with Rawls readily acknowledge that in certain social circumstances-say, in societies threatened by instability, or that suffer from class or race inequality and segregationsecuring political justice and legitimacy may require that students share schools and curriculum irrespective of their wishes or those of their parents (see Davis and Neufeld 2007, Neufeld 2013).

The political liberal conception of full political autonomy, and the role of public reason with respect to the realization of that conception, can be interpreted as an account of how a version of Rousseau's ideal of a self-governing citizenry might be realized in contemporary pluralist societies. A pluralist society in which citizens are equal co-sovereigns is a 'realistic utopia' (Rawls 2001). Realizing the political liberal version of this ideal has significant educational implications. Students must be taught to be capable of being reasonable and rational persons. Whether such an education necessarily involves teaching students a form of comprehensive autonomy has been debated since the publication of Political Liberalism - and continues to be debated by political and educational theorists. 


\section{References}

Benn, S (1988) A Theory of Freedom. Cambridge University Press, Cambridge.

Brighouse, H (1994) Is There Any Such Thing as Political Liberalism? Pacific Philosophical Quarterly 75: 318-332.

Callan E (1996) Political Liberalism and Political Education. Review of Politics 58: 5-33.

Callan E (1997) Creating Citizens: Political Education and Liberal Democracy. Oxford University Press, Oxford.

Cohen J (1994) A More Democratic Liberalism. Michigan Law Review 92: 1503-1546.

Cohen J (2008) Procedure and Substance in Deliberative Democracy. In Cohen J, Philosophy, Politics, Democracy. Harvard University Press, Cambridge, MA, pp.154-180.

Costa V (2011) Rawls, Citizenship, and Education. Routledge, New York.

Darwall S (1995) Two Kinds of Respect. In R.S. Dillon (ed) Dignity, Character, and Self-Respect. Routledge, New York, pp.181-197.

Darwall S (2006) The Second-Person Standpoint. Harvard University Press, Cambridge MA.

Davis G, Neufeld B (2007) Political Liberalism, Civic Education, and Educational Choice. Social Theory and Practice 33: 47-74.

De Wijze S (1999) Rawls and Civic Education. Cogito 13: 87-93.

Dworkin, G (1988) The Theory and Practice of Autonomy. Cambridge University Press, Cambridge.

Ebels-Duggan K (2013) Moral Education in the Liberal State. Journal of Practical Ethics 1: 3463.

Edenberg E (2016) Civic Education: Political or Comprehensive? In Drerup J, et al (eds) Justice, Education and the Politics of Childhood: Challenges and Perspectives. Springer, Dordrecht, pp.187-206.

Gutmann A (1995) Civic Education and Social Diversity. Ethics 105: 557-579.

Kymlicka W (2001) Politics in the Vernacular: Nationalism, Multiculturalism, and Citizenship. Oxford University Press, Oxford.

Larmore C (1987) Patterns of Moral Complexity. Cambridge University Press, Cambridge.

Larmore C (2008) The Autonomy of Morality. Cambridge University Press, Cambridge. 
Lister A (2018) The Coherence of Public Reason. Journal of Moral Philosophy 15: 64-84.

Macedo S (2000) Diversity and Distrust: Civic Education in a Multicultural Democracy. Harvard Univerity Press, Cambridge MA.

Neufeld B (2005) Civic Respect, Political Liberalism, and Non-Liberal Societies. Politics, Philosophy \& Economics 4: 275-299.

Neufeld B (2013) Political Liberalism and Citizenship Education. Philosophy Compass 8: 781 797.

Neufeld B (2019) Shared Intentions, Public Reason, and Political Autonomy. Canadian Journal of Philosophy 49: 776-804

Nussbaum M (2011) Perfectionist Liberalism and Political Liberalism. Philosophy \& Public Affairs 39: 3-45.

Peter F (2013) Epistemic Foundations of Political Liberalism. Journal of Moral Philosophy 10: 598-620.

Quong J (2011) Liberalism without Perfection. Oxford University Press, Oxford.

Rawls J (1999) A Theory of Justice: Revised Edition. Harvard University Press, Cambridge MA. (Original edition 1971.)

Rawls J (2001) Justice as Fairness: A Restatement. Harvard University Press, Cambridge MA.

Rawls J (2005) Political Liberalism: Expanded Edition. Columbia University Press, New York. (Original edition 1993.)

Reich R (2002) Bridging Liberalism and Multiculturalism in American Education. University of Chicago Press, Chicago.

Rousseau, J-J (1968) The Social Contract. Cranston M (trans). Penguin Books, London.

Schouten G (2018) Political Liberalism and Autonomy Education: Are Citizenship-Based Arguments Enough? Philosophical Studies 175: 1071-93.

Strike K (1996) Must Liberal Citizens be Reasonable? The Review of Politics 58: 41-48.

Watson C and Hartley C (2018) Equal Citizenship and Public Reason: A Feminist Political Liberalism. Oxford University Press, Oxford.

Weithman P (2010) Why Political Liberalism? On John Rawls's Political Turn. Oxford University Press, Oxford.

Weithman P (2011) Convergence and Political Autonomy. Public Affairs Quarterly 25: 327-348. 
Weithman P (2017) Autonomy and Disagreement about Justice in Political Liberalism. Ethics 128: 95-122.

Weithman P (2018) In Defense of a Political Liberalism. Philosopby \& Public Affairs 45: 397412.

Wenar, L (1995) Political Liberalism: An Internal Critique. Ethics 106: 32-62. 